\title{
Problem-Based Learning and Learning Styles: The impact on Student's Learning Outcomes
}

\author{
Susan Febriantina1; Nuryetty Zein ${ }^{2}$; Indah Novita3; ${ }^{3}$ Marsofiyati ${ }^{4}$ \\ Faculty of Economics, State University of Jakarta \\ E-mail: susanfebriantina@unj.ac.id
}

\begin{abstract}
This study aimed to determine the magnitude of the influence of the problem-based learning model and learning styles on student learning outcomes at SMK Bina Pangudi Luhur Jakarta. The research method used in this study was a survey method with a population of 105 students in the $\mathrm{X}$ grade and the sampling technique was proportional random sampling. The result was a significant direct and indirect influence between the problem-based learning model on student learning outcomes, learning styles on learning outcomes, the problem-based learning model on student learning styles, as well as the problem-based learning models and learning styles on the learning outcomes of students of class X at SMK Bina Pangudi Luhur Jakarta. In addition to the problem-based learning model and learning style, student learning outcomes were also influenced by other factors. Therefore, further research can examine more closely the other factors that influence student learning outcomes.
\end{abstract}

Keywords: Problem Based Learning, Learning Style, Learning Outcomes

\section{INTRODUCTION}

One of the challenges for teachers in the digital era today is creating effective, active, creative, and innovative learning to improve student learning outcomes (Huang, 2018). By an effective, active, creative, and innovative learning approach, students do not only avoid bored but also stimulate students to communicate ideas verbally and in writing so it is easy to understand the material and get a maximum score on the learning outcomes (Bajaj and Sharma, 2018). An exciting, fun and interesting way to learn students can be done by using student-centered learning methods (Magdalena, 2015). Problem Based Learning (PBL) is one of the learning models that direct students to have a desire to understand, studying good learning needs so they want to use and find the best learning resources to solve the problems they face. Several previous studies related to the effect of problem-based learning on improving student learning outcomes have been carried out, among them (Andersen et al., 2019), (Liu et al., 2019), and (Wyness and Dalton, 2018). Problem-based learning cannot be carried out if the teacher does not develop a classroom environment that allows for an open exchange of ideas. In essence, students will be confronted with authentic and meaningful problem situations that can challenge students to solve them. PBL is a simulation problem that can be used to activate the curiosity of students before starting to learn an object, so students can think critically and be able to get and use learning resources appropriately (Phungsuk et al., 2017). Broadly, PBL is a learning that requires students to learn independently individually or in groups to solve problems presented by the teacher. The teacher has a role in presenting problems and asking questions that direct students to solve a problem in learning activities (Matewos et al., 2019).

Amir (2009) stated, PBL is done by giving "problems" usually "real world" that is the real world as a context for students to learn about critical thinking and 
problem-solving skills. In line with Amir, Duch in Aris Shoimin (2014) stated that problem-based learning (PBL) is a model that discusses differences opinion about students learning critical thinking and problem-solving skills and gaining knowledge. Likewise, Arend in Trianto (2007), which stated that PBL as a learning approach where students are faced with solving authentic (real) problems so that they are expected to be able to compile their knowledge, develop high-level skills and inquiry, develop students' independence, and increase their confidence. While Barell (2007) argued, problem-based learning can be defined as an inquiry process that resolves questions, curiosities, doubts, and uncertainties about complex phenomena in life.

Meanwhile, to measure the success of the learning process, it can be seen from the extent to which students gain learning experiences or gain something from the learning process above (Bota and Petre, 2015). Norma and Jennifer (2009) stated that learning outcomes are statements of what students should know, understand and/or be able to demonstrate after completion of a process of learning. Learning outcomes can also measure the level of student success in learning subject matter at school stated in the scores achieved from test results regarding several specific subject matters (Nawawi (2014). Shah (2010), stated that learning outcomes are a reflection of the achievements of a student to a particular teaching program under predetermined criteria, while Sanjaya (2008) argued that learning outcomes are related to achievement in gaining abilities following specific objectives planned.

Learning outcomes achieved by students are influenced by two factors, which are those that originate from within the student (internal) and from outside the student (external). According to Slamento (2013), the factors that influence learning outcomes are:

1. Internal factors include physical or spiritual state or condition of students.

2. External factors include environmental conditions around students, such as family environmental factors, peer environment, and community environment

Students' varied learning styles can also cause differences in the achievement of their learning outcomes (Huang, 2018). One's learning style influences one's learning style, so someone will find it easier to learn and communicate according to each individual's unique style (Tutticci et al., 2016). Likewise, with a student, he will more easily learn and find ways of learning. It can be said that the learning style plays an important role in one's learning success (Magdalena, 2015). The learning style of each student is a combination of how he absorbs and then organizes and processes information. Basically, students have their respective characteristics and therefore, there are no students the same, each other is certainly different. The students differ from their personality, intelligence, physical, social and emotional (Belousova, 2014). Some are slow and some are fast learners. Differences also occur in the learning styles of each student, some are more in line with certain learning styles and some are not following these styles (Chou, 2018).

Priyatna (2013) stated, learning styles are ways in which children receive new information and the processes they will use to learn. Whereas Gunawan (2004) argued, learning styles are the preferred way to do activities of thinking, 
processing and understanding information. Meanwhile, Marlene (2004) stated that learning style is how a person sees or perceives things best and then processes or uses what has been seen and each individual's learning style is as unique as a signature. Based on the opinions of the four experts above, researchers interpret learning styles as the preferred way for students to understand information, process information, and remember information that is conveyed during teaching and learning activities.

Learning style itself consists of 3 (three) types, namely visual, auditory, and kinaesthetic.

1. Visual learning style

According to Rusman (Rusman, 2015), a visual learning style is a learning style where ideas, concepts, data, and other information are packaged in the form of images.

2. Auditory learning styles

Auditory learning style is a learning style where children more easily capture information or knowledge through listening (sense of the ear).

3. Kinesthetic learning styles

Kinesthetic learning styles are learning by doing, touching, feeling, moving, and experiencing.

Students who tend to have a visual learning style will love to wear colorful and stylish clothes because they are aware of their appearance. Children with visual learning styles usually have a strong sensitivity to colors, besides having a sufficient understanding of artistic problems. Visual children usually have to see the evidence and then they can trust it. In addition, children who are visual type will quickly learn the materials presented in writing, charts, graphs, pictures. Conversely, it will be difficult to learn when confronted with materials in the form of sound or movement (Qureshi et al., 2016).

Students who tend to have auditory learning styles can focus internally and externally (Stekelenburg and Vroomen, 2015). The external auditor likes to talk and will talk to themselves when learning. Meanwhile, learners who tend to be internal will say to themselves inside their heads, but when viewed from the outside, the only habit that is seen is silence (Bayona and Castañeda, 2017). Students, who are auditory type, easily learn the materials presented in the form of sound (lecture). While students who tend to have kinaesthetic learning styles can manifest themselves internally and externally (Bakar, 2018). External kinetic learners prefer physical touch, that is, they prefer learning by trying something using their hands and then taking notes during the learning process. Whereas internal kinesthetic learners prefer to feel their emotions about the learning process, before accepting it (Munastiwi, 2015).

The following is data on the learning styles of Grade X students of Office Administration in SMK Bina Pangudi Luhur Jakarta on correspondence subjects. 


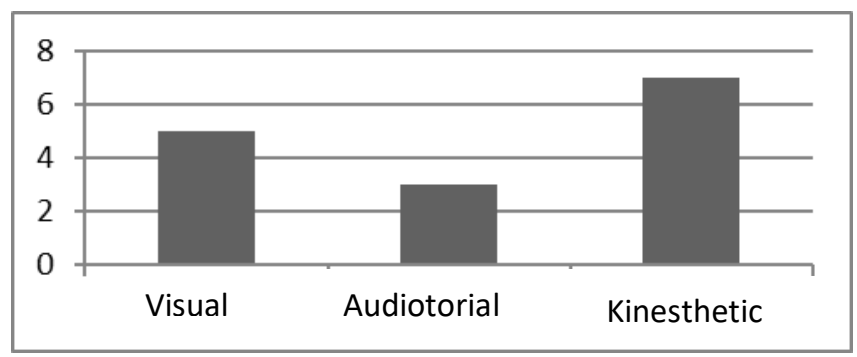

Figure 1 Data on student learning styles

Based on the questionnaire distributed to students of class $\mathrm{X}$ above, it could be seen that in general students of class $X$ in Office Administration at SMK Bina Pangudi Luhur Jakarta had a kinesthetic learning style.

The following are the midterm assessment data (PTS) on the X class X AP correspondence subjects in SMK Bina Pangudi Luhur Jakarta:

Table 1 Average appraisal of PTS Even Class X Office Administration Vocational School Bina Pangudi Luhur Jakarta 2018/2019

\begin{tabular}{clll}
\hline No. & Class & $\begin{array}{l}\text { Average } \\
\text { Score PTS }\end{array}$ & $\begin{array}{l}\text { Minimum } \\
\text { Learning } \\
\text { Mastery } \\
\text { Standard } \\
\text { Score }\end{array}$ \\
\hline 1 & X AP 1 & 70,35 & \\
2 & X AP 2 & 60,59 & 75 \\
3 & X AP 3 & 68,70 & \\
\hline
\end{tabular}

Based on the data above, it could be seen that most of the tenth-grade students of SMK Bina Pangudi Luhur Jakarta in 2018 who also generally had a kinesthetic learning style had an average PTS value below the Minimum Learning Mastery Standard (KKM) Score. Thus, that the learning outcomes of SMK Bina Pangudi Luhur Jakarta students could be achieved optimally, it was necessary to apply learning models in addition to conventional learning models in the form of lectures (Mubuuke et al., 2017). A Problem-based learning model that refers to the activeness of students in teaching and learning activities, as well as the teacher's understanding of student learning styles, is considered able to improve the quality of the learning process and student learning outcomes (Yew and Goh, 2016). This happens so that students can be more independent in understanding the material and also understand the learning style that they like so that it is easy to absorb a material (Mynott, 2018).

\section{METHOD}

This study used a survey method with a path analysis approach. The researcher used primary data for the variable model of problem-based learning (X1) and learning styles (X2) and secondary data in the form of students' final semester scores for the Learning Outcomes variable (Y). The affordable population in this 
study was 150 students of X class in SMK Bina Pangudi Luhur, while the sampling technique used in this study was proportional random sampling.

\section{RESULT \& DISCUSSION}

Based on the results of path analysis research, together the influence of problembased learning models and visual, auditory, kinaesthetic learning styles on learning outcomes obtained the coefficient of determination by looking at R2 of 0.341 . This explained that the independent variables of the problem-based learning (X1) and learning styles (X2.1, X2.2, X2.3) simultaneously contributed 34.1\% and the other $65.9 \%$ were contributions from other variables not researched. The framework of the test results between X1, X2.1, X2.2, and X2.3 against $\mathrm{Y}$ could be made through the structural equation as follows:

$$
\begin{gathered}
\mathrm{Y}=\operatorname{pyx}_{1} \mathrm{X}_{1}+\operatorname{pyx}_{2.1} \mathrm{X}_{2.1}+\operatorname{pyx}_{2.2} \mathrm{X}_{2.2}+\operatorname{pyx}_{2.3} \mathrm{X}_{2.3}+\mathrm{py} \boldsymbol{\varepsilon}_{\mathbf{1}} \\
\mathrm{Y}=0,358+0,209+0,237+0,310+0,659 \boldsymbol{\varepsilon}_{\mathbf{1}}
\end{gathered}
$$

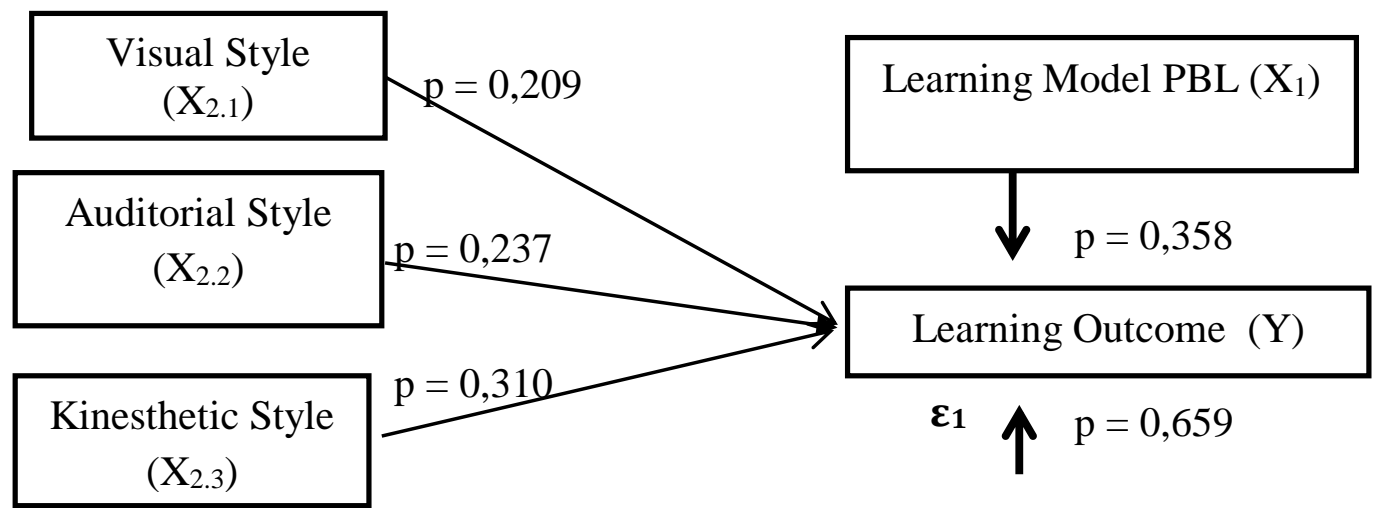

Figure 2 Structure Test Results 2 Effect of Problem Based Learning Model Learning, Visual Style, Auditory Style, and Kinesthetic Style on Learning Outcomes

From the results of hypothesis testing it could be concluded that there was a direct effect of the problem-based learning model of learning on learning outcomes of 0.358 . The results of the above study were in line with research conducted by Eti Sunarsih, et al (2018) which proved that the problem-based learning model has a significant effect on learning outcomes. There was a direct influence of visual style on learning outcomes of 0.209 , direct influence of auditory style on learning outcomes of 0.237 , direct influence of kinaesthetic style on learning outcomes of 0.310 . There was the influence of the problem-based learning model of learning outcomes of a total of 0.432 including the direct effect of 0.358 and the indirect effect through the visual style of 0.074 , the influence of the problem based learning model of learning towards a total learning outcome of 0.442 including the direct effect of 0.358 and the indirect effect direct through the auditory style of 0.084 , the influence of the kinaesthetic style on learning outcomes in total of 0.468 included a direct effect of 0.358 and an indirect effect through the kinaesthetic style of 0.110 . This was in line with the theory by Darmadi (2017) 
which stated that different learning styles of students could help teachers deliver learning materials to all students so that learning outcomes would be more effective.

Based on the results of calculations in this study, the indicators of critical thinking in the problem-based learning model obtained the highest results in the amount of 50.61\%. This was in line with the previous theory by Putra (2013) and Amir (2009) which stated that problems provide opportunities to increase motivation in students and motivation would encourage students to think of problems that were presented with both the causes and the most appropriate solutions so that when given questions about other problems, students could analyse them smoothly and the expected learning outcomes would be achieved. Then, the learning style variable visual style indicators obtained the highest results that were equal to 35.90. Then, based on hypothesis testing, it was proven that kinaesthetic learning style had a higher effect on learning outcomes by $31 \%$ compared to visual learning and auditory learning styles. This was in line with research conducted by Imro'atul Hasanah, Sri Kantun, and Sutrisno Djaja (2018) which stated that learning styles have a joint and dominant influence between visual learning styles, auditory learning styles, and learning styles kinaesthetic towards student learning outcomes.

Based on the Statistical Package for the Social Science (SPSS) output that had been done, it could be interpreted that the problem-based learning model affected learning outcomes, meaning that the better the model of problem-based learning, the better the learning outcomes and vice versa. Learning styles also affected learning outcomes, the better the learning styles, the better the learning outcomes and vice versa. Thus it could be concluded, if the model of problem-based learning and learning style was good, the better the learning outcomes obtained by students (Donnell et al., 2018).

\section{CONCLUSION}

Based on the results of data analysis above, it could be concluded that; 1 ) there was a significant direct and indirect influence between the problem-based learning model of learning outcomes of students in X class at SMK Bina Pangudi Luhur Jakarta; 2) there was a significant direct effect between learning styles on the student learning outcomes in X class at SMK Bina Pangudi Luhur Jakarta; 3) there was a significant direct effect between the problem-based learning model of learning styles of X class at SMK Bina Pangudi Luhur Jakarta; and 4) there is a significant direct effect between the problem-based learning model and learning style on the student learning outcomes in X class at SMK Bina Pangudi Luhur Jakarta. In addition to the problem-based learning model and learning style, student learning outcomes were also influenced by other factors. Therefore, further research can examine more closely the other factors that influence student learning outcomes. 


\section{REFERENCES}

Amir, T., 2009. Inovasi Pendidikan Melalui Problem Based Learning. Jakarta: Prenada Media Group.

Andersen, A.L., Brunoe, T.D., \& Nielsen, K., 2019. Engineering education in changeable and reconfigurable manufacturing: Using problem-based learning in a learning factory environment. Procedia CIRP 81, 7-12. https://doi.org/10.1016/j.procir.2019.03.002.

Bajaj, R., \& Sharma, V., 2018. Smart Education with artificial intelligence based determination of learning styles. Procedia Comput. Sci. 132, 834-842. https://doi.org/10.1016/j.procs.2018.05.095.

Bayona, J.A., \& Castañeda, D.I., 2017. Influence of personality and motivation on case method teaching. Int. J. Manag. Educ. 15, 409-428. https://doi.org/10.1016/j.ijme.2017.07.002.

Belousova, A., 2014. Thinking Style as a Factor of Variable Cognitive Education. Procedia - Soc. Behav. Sci., LUMEN 2014 - From Theory to Inquiry in Social Sciences, Iasi, Romania, 10-12 April 2014 149, 97-101. https://doi.org/10.1016/j.sbspro.2014.08.167.

Bota, O.A., \& Petre, C., 2015. Educational Style Impact on Student Academical Achievements. Procedia - Soc. Behav. Sci., First Global Conference on Contemporary Issues in Education (GLOBE-EDU 2014) 12-14 July 2014, Las Vegas, USA 177, 127-131. https://doi.org/10.1016/j.sbspro.2015.02.360.

Chou, D.C., 2018. Applying design thinking method to social entrepreneurship project. Comput. Stand. Interfaces 55, 73-79. https://doi.org/10.1016/j.csi.2017.05.001.

Donnell, Z., Hoffman, R., Sarmiento, K., \& Hays, C., 2018. Concussion attitudes, behaviors, and education among youth ages 12-17: Results from the 2014 YouthStyles survey. J. Safety Res. 64, 163-169. https://doi.org/10.1016/j.jsr.2017.12.001.

Huang, T.-C., 2018. Do different learning styles make a difference when it comes to creativity? An empirical study. Comput. Hum. Behav. https://doi.org/10.1016/j.chb.2018.10.003.

Liu, L., Du, X., Zhang, Z., \& Zhou, J., 2019. Effect of problem-based learning in pharmacology education: A meta-analysis. Stud. Educ. Eval. 60, 43-58. https://doi.org/10.1016/j.stueduc.2018.11.004

Magdalena, S.M., 2015. The Relationship of Learning Styles, Learning Behaviour and Learning Outcomes at the Romanian Students. Procedia - Soc. Behav. Sci. 180, 1667-1672. https://doi.org/10.1016/j.sbspro.2015.05.062.

Matewos, A.M., Marsh, J.A., McKibben, S., Sinatra, G.M., Le, Q.T., \& Polikoff, M.S., 2019. Teacher learning from supplementary curricular materials: Shifting instructional roles. Teach. Teach. Educ. 83, 212-224. https://doi.org/10.1016/j.tate.2019.04.005.

Mubuuke, A.G., Louw, A.J.N., \& Van Schalkwyk, S., 2017. Cognitive and Social Factors Influencing Students' Response and Utilization of Facilitator Feedback in a Problem Based Learning Context. Health Prof. Educ. 3, 85-98. https://doi.org/10.1016/j.hpe.2016.09.003.

Munastiwi, E., 2015. The Management Model of Vocational Education Quality Assurance Using 'Holistic Skills Education (Holsked).' Procedia - Soc. Behav. 
Sci., The 4th World Congress on Technical Vocational Education and Training (4thWoCTVET), 5-6 December 2014, Universiti Tun Hussein Onn Malaysia, MALAYSIA 204, 218-230. https://doi.org/10.1016/j.sbspro.2015.08.144.

Mynott, G.J., 2018. The academic self-concept of business and management students: A review of the literature. Int. J. Manag. Educ. 16, 515-523. https://doi.org/10.1016/j.ijme.2018.10.003.

Phungsuk, R., Viriyavejakul, C., \& Ratanaolarn, T., 2017. Development of a problembased learning model via a virtual learning environment. Kasetsart J. Soc. Sci. 38, 297-306. https://doi.org/10.1016/j.kjss.2017.01.001.

Stekelenburg, J.J., \& Vroomen, J., 2015. Predictive coding of visual-auditory and motor-auditory events: An electrophysiological study. Brain Res., Predictive and Attentive Processing in Perception and Action 1626, 88-96. https://doi.org/10.1016/j.brainres.2015.01.036.

Tutticci, N., Coyer, F., Lewis, P.A., \& Ryan, M., 2016. High-Fidelity Simulation: Descriptive Analysis of Student Learning Styles. Clin. Simul. Nurs. 12, 511521. https://doi.org/10.1016/j.ecns.2016.07.008.

Wyness, L., \& Dalton, F., 2018. The value of problem-based learning in learning for sustainability: Undergraduate accounting student perspectives. J. Account. Educ. 45, 1-19. https://doi.org/10.1016/j.jaccedu.2018.09.001.

Yew, E.H.J., \& Goh, K., 2016. Problem-Based Learning: An Overview of its Process and Impact on Learning. Health Prof. Educ. 2, 75-79. https://doi.org/10.1016/j.hpe.2016.01.004. 